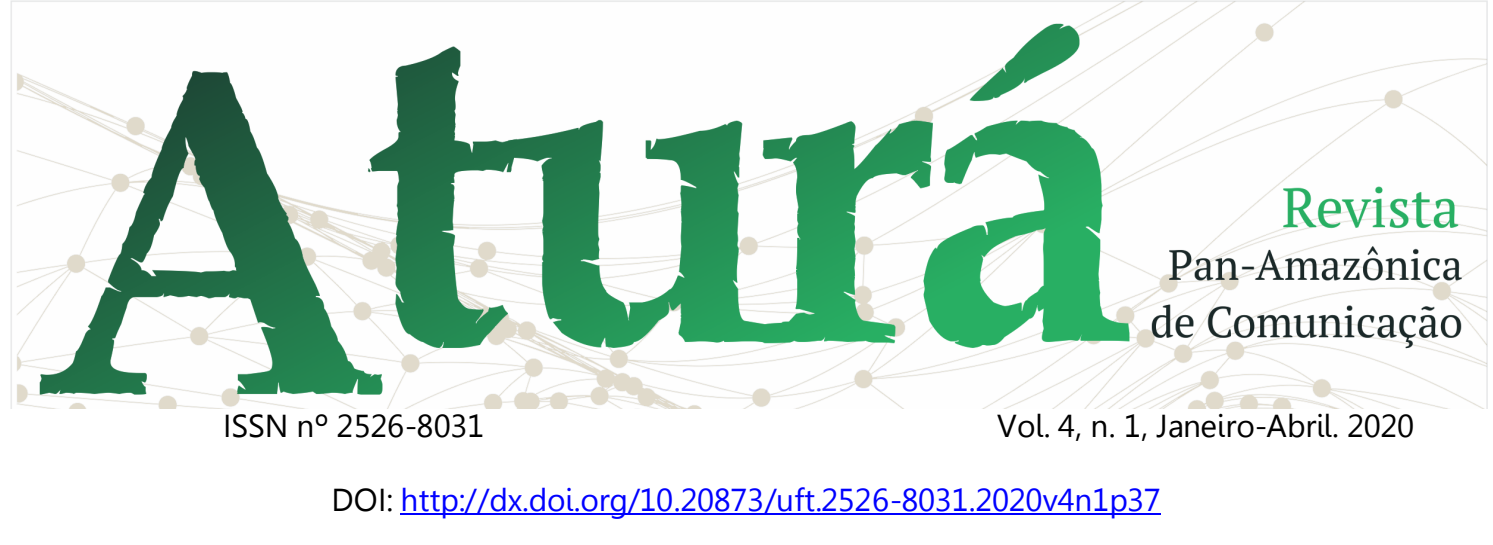

\title{
AS MORTES DE SENHORITA ANDREZA: modos de acionamento das colonialidades
}

The Deaths of Senhorita Andreza: ways in which colonialities are triggered

Las Muertes de Señorita Andreza: formas en que se desencadenaron las colonialidades

\section{Guilherme Guerreiro Neto ${ }^{1}$ \\ Raissa Lennon Nascimento Sousa ${ }^{2}$ \\ Vivian de Nazareth Santos Carvalho $0^{3,4}$}

\section{RESUMO}

O objetivo deste artigo é analisar os modos de acionamento das colonialidades (QUIJANO, 2005, 2009, 2014; MALDONADO-TORRES, 2007; LUGONES, 2014) no limiar entre a existência e as mortes sociais de Senhorita Andreza, mulher negra da periferia de Belém (PA) que se tornou "celebridade" repentina e, meses depois, acabou assassinada. Como as colonialidades atuam no processo de visibilização de sujeitos subalternizados? A partir dessa questão-problema, o caminho metodológico segue a análise de quatro acontecimentos-chave e seus desdobramentos no período de exposição pública da imagem de Andreza, entre janeiro de 2016 e abril de 2017, tendo excertos midiáticos como empiria. As colonialidades que atravessam a visibilização de Senhorita Andreza se apresentam nas formas de 1) celebrificação pela via do risível e julgamento público, 2) criminalização, escárnio e racismo institucional, 3) presença fora do lugar na disputa políticopartidária, 4) assassinato e negação do luto. Há, portanto, uma visibilização desumanizante, uma visibilidade incompleta, que não garante reconhecimento.

\footnotetext{
${ }^{1}$ Doutorando do Programa de Pós-Graduação em Desenvolvimento Sustentável do Trópico Úmido (PPGDSTU) no Núcleo de Altos Estudos Amazônicos da Universidade Federal do Pará (NAEA/UFPA), e-mail: gguerreironeto@gmail.com.

2 Doutoranda do Programa de Pós-Graduação Comunicação, Cultura e Amazônia da Universidade Federal do Pará (PPGCOM/UFPA), e-mail: lennonraissa@gmail.com.

${ }^{3}$ Doutoranda do Programa de Pós-Graduação em Letras da Universidade Federal do Pará (PPGL/UFPA), e-mail: viviansantoscarvalho@gmail.com.

${ }^{4}$ Endereço de contato com os autores (por correio): Universidade Federal do Pará. Cidade Universitária José da Silveira Netto. Av. Augusto Corrêa, nº 01, Guamá - Belém-PA - Brasil. CEP 66.075-110.
} 


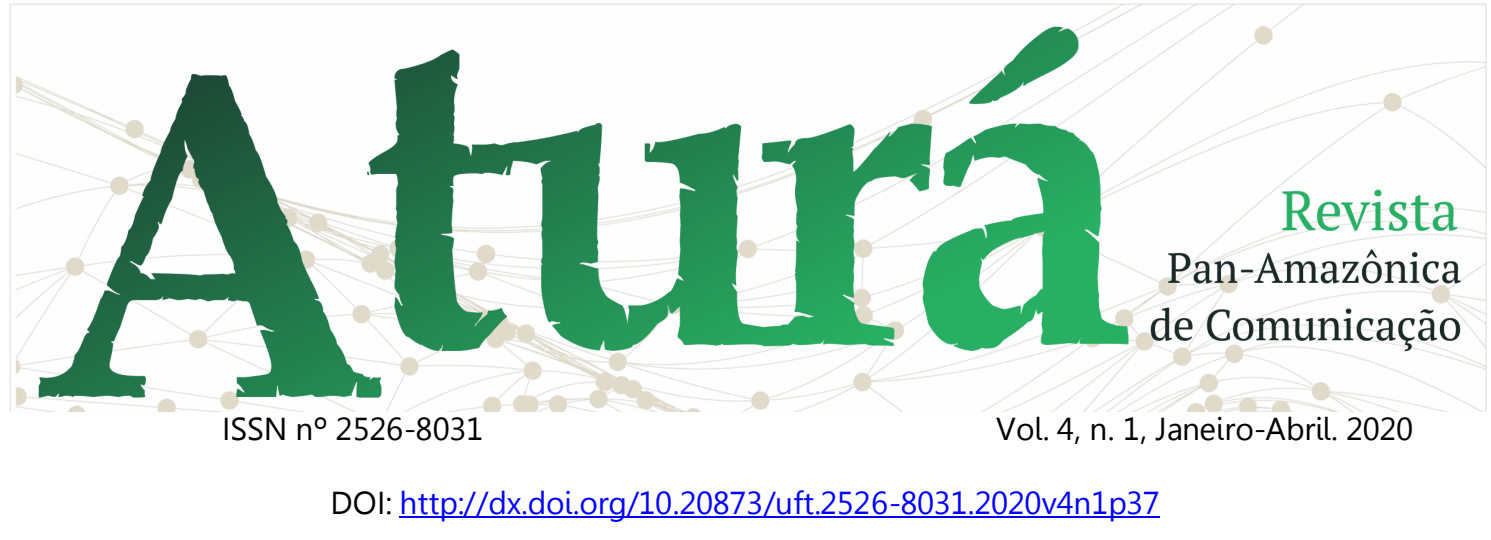

PALAVRAS-CHAVE: Colonialidade; Visibilização; Morte social; Senhorita Andreza.

\section{ABSTRACT}

The purpose of this article is to analyze the ways in which colonialities (QUIJANO, 2005, 2009, 2014; MALDONADO-TORRES, 2007; LUGONES, 2014) are triggered on the threshold between the existence and the social deaths of Senhorita Andreza, black woman from the outskirts of Belém (PA) who became a sudden celebrity and, months later, ended up murdered. How do colonialities act in the process of making subaltern subjects visible? Based on this problem-issue, the methodological path follows the analysis of four key events and their developments in the period of public exposure of Andreza's image, between January 2016 and April 2017, having media excerpts as empirics. The colonialities that go through the visibility of Senhorita Andreza are presented in the forms of 1 ) celebrification through laughter and public judgment, 2) criminalization, scorn and institutional racism, 3) out of place presence in the political-party dispute, 4) murder and grief denial. There is, therefore, a dehumanizing visibility, incomplete visibility, that does not guarantee recognition.

KEYWORDS: Coloniality; Visibilization; Social death; Senhorita Andreza.

\section{RESUMEN}

El propósito de este artículo es analizar las formas en que se desencadenaron las colonialidades (QUIJANO, 2005, 2009, 2014; MALDONADO-TORRES, 2007; LUGONES, 2014) en el umbral entre la existencia y la muerte social de Señorita Andreza, una mujer negra de las afueras de Belém (PA) que se convirtió en una celebridad repentina y, meses después, terminó asesinada. ¿Cómo actúan las colonialidades en el proceso de hacer visibles los sujetos subalternos? Sobre la base de este pregunta-problema, la ruta metodológica sigue el análisis de cuatro eventos clave y sus desarrollos en el período de exposición pública de la imagen de Andreza, entre enero de 2016 y abril de 2017, con extractos de los medios de comunicación como empíricos. Las colonialidades que pasan por la visibilización de la Señorita Andreza se presentan en forma de 1) celebrización a través de la risa y el juicio público, 2) criminalización, desprecio y racismo institucional, 3) presencia fuera de lugar en la disputa de los partidos políticos, 4) asesinato y negación del luto. Existe, por lo tanto, una visibilización deshumanizante, visibilidad incompleta, que no garantiza el reconocimiento.

PALABRAS CLAVE: Colonialidad; Visibilización; Muerte social; Señorita Andreza.

Recebido em: 12.11.2019. Aceito em: 12.12.2019. Publicado em: 03.01.2020. 


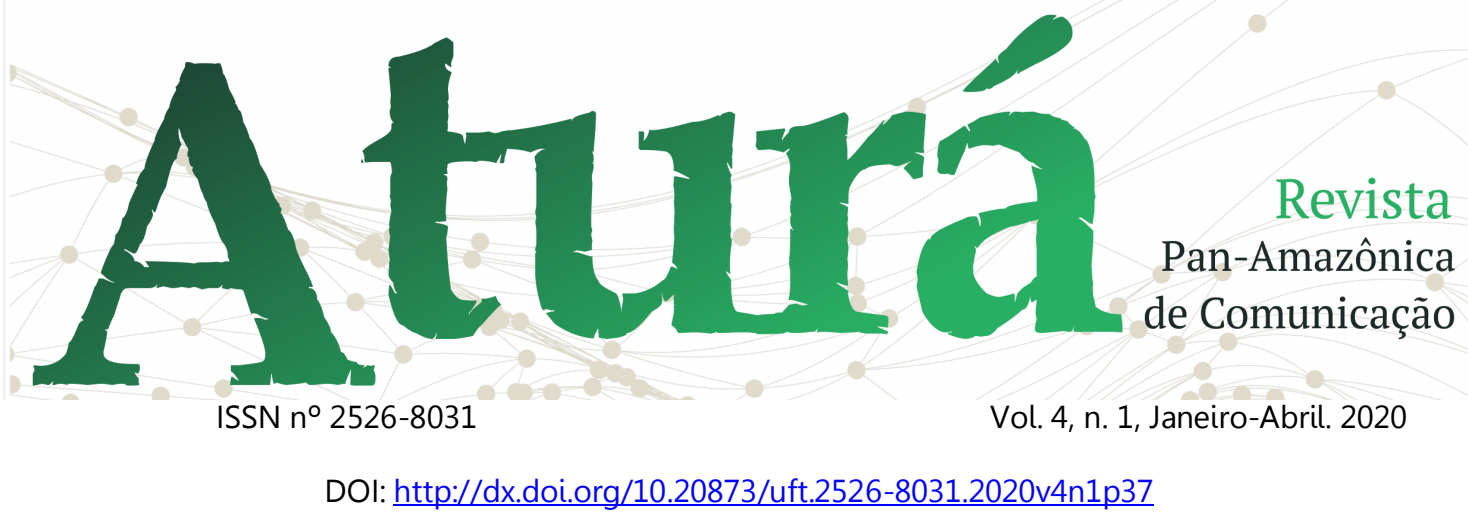

Introdução

A paraense Andreza Ariani Castro de Souza, em um intervalo de um ano e três meses, tornou-se repentina celebridade local, encarou o escárnio público e a cadeia, fez incursão na política partidária e viu a morte chegar prematuramente, aos 22 anos. Ela ficou conhecida como Senhorita Andreza. Jovem mulher negra do bairro da Cabanagem, na periferia de Belém, Andreza fugiu à regra de total invisibilidade que marca boa parte das vidas marginalizadas de seu entorno. Mas as imagens que the couberam foram atravessadas por colonialidades. Antes e depois de ser assassinada, ela passou por situações de morte social que atuaram como formas de desumanização. Este texto trata das mortes - e das tentativas de restituição da vida - de Senhorita Andreza.

Como as colonialidades, fundadas em classificações sociais de raça, gênero e classe, atuam no processo de visibilização de sujeitos subalternizados? A partir dessa questão-problema, nosso objetivo é analisar modos de acionamento dessas colonialidades no limiar entre a existência e as mortes sociais de Senhorita Andreza. O caminho metodológico segue a análise de quatro acontecimentos-chave e seus desdobramentos no período de exposição pública da imagem de Andreza de Souza, entre janeiro de 2016 e abril de 2017. Compõem a empiria excertos midiáticos como vídeos de Andreza, postagens/comentários em sites de rede social e materiais publicados/exibidos na imprensa paraense.

A colonialidade do poder, conceito proposto por Aníbal Quijano e retrabalhado por vários autores latinoamericanos, é mais profunda e duradoura que o colonialismo, o sistema histórico de exploração. Não se trata de uma ideia relacionada ao passado, mas ao presente ou ao menos ao passado que se reproduz e se atualiza no presente -, estando emaranhada nas relações sociais do cotidiano. A matriz colonial de poder é fundada em classificações sociais padrões de distribuição do poder definidos por processos de longo prazo e 


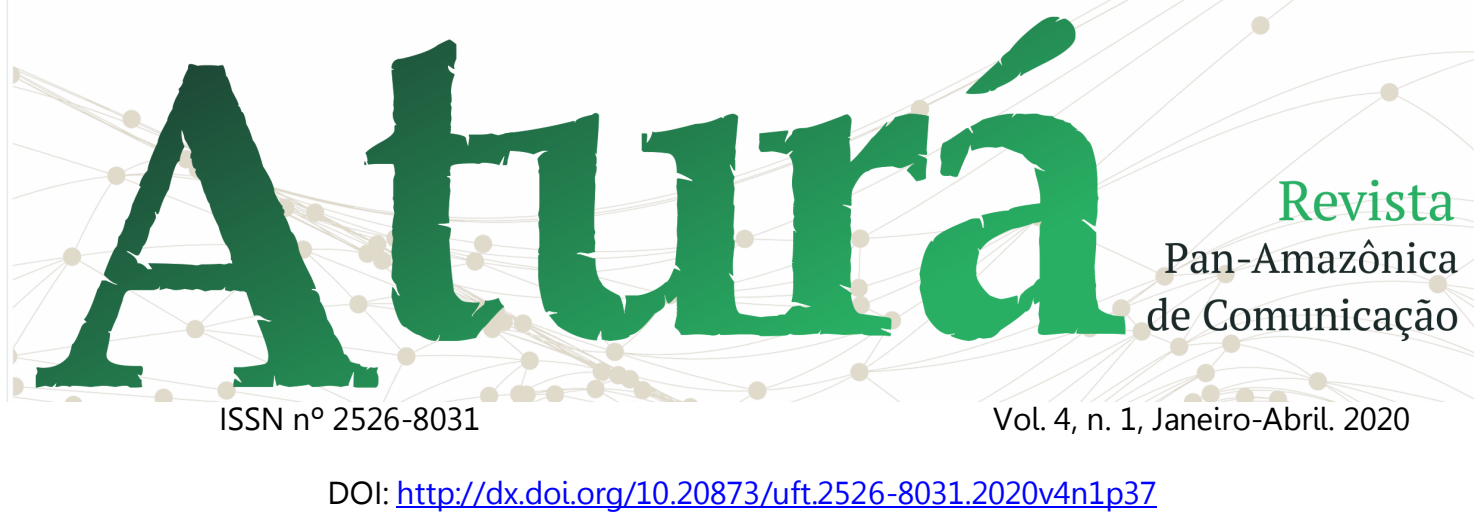

centrados em relações de dominação (QUIJANO, 2009) - de cunho racial, étnico, sexual, de gênero, de classe, de trabalho.

A experiência vivida desse processo de inferiorização é compreendida pela ideia de colonialidade do ser (MALDONADO-TORRES, 2007). Haveria uma naturalização da não ética de guerra nas violações e na morte imputadas aos corpos racializados e colonizados. Esse sujeito que emerge no mundo atravessado pela colonialidade do ser é uma espécie de condenado, que Frantz Fanon (2005) chama de damné. Mas é também um ser de lócus fraturado (LUGONES, 2014), capaz de resistir à opressão. De todo modo, há uma ferida colonial (MIGNOLO, 2007), física ou psicológica, como consequência do racismo e de outras classificações sociais, ou seja, fruto do golpe no humano que há nesses sujeitos.

As mortes sociais de Senhorita Andreza, sua expulsão para fora da humanidade (MBEMBE, 2018), acabam por expor a ferida que a acompanha. Neste artigo, propomos percorrer os momentos de visibilização que Andreza teve, identificando a presença das colonialidades nos processos de morte social. Cada seção trata de algum dos episódios e seu contexto: 1) a viralização do vídeo e a celebrificação pelo risível, 2) a criminalização, a prisão e o escárnio midiático-institucional, 3) a candidatura política e o deslocamento de lugar e 4) a morte física e o questionamento do luto. Além dos estudos decoloniais e póscoloniais, são fundamentais para a discussão autoras do feminismo negro, como Patricia Hill Collins (2019) e Lélia Gonzalez (2018).

\section{Celebrificação e Embaçamentos}

Fala aí, comunidade! Tudo certo, meu mano? Por aqui e tal só pra avisar e tal pra quem não tá esperto da social que vai dar o que falar dia 23 aí, aqui na casa da Senhorita Andreza, tá ligado? Periquita? Vai ter muita, só as despintada. Os cara doido? Também, mano, vão tudo comparecer, tá ligado. Vamo beber um chopp, cheirar uma coca na manha, sem embaçamento. Éééé, sem embaçamento, é tudo certo, tá ligado? Campinho pra legalizar a erva da Jamaica, porque tem que ter, mano. Tu num tá doido de perder essa, meu mano! Ventimbora fechar com o Sérgio, tá ligado? É aqui no setor da Senhorita Andreza e tal, vai dar o que falar. É, mano, boca de se foder. Ventimbora que é nós, caralho! 


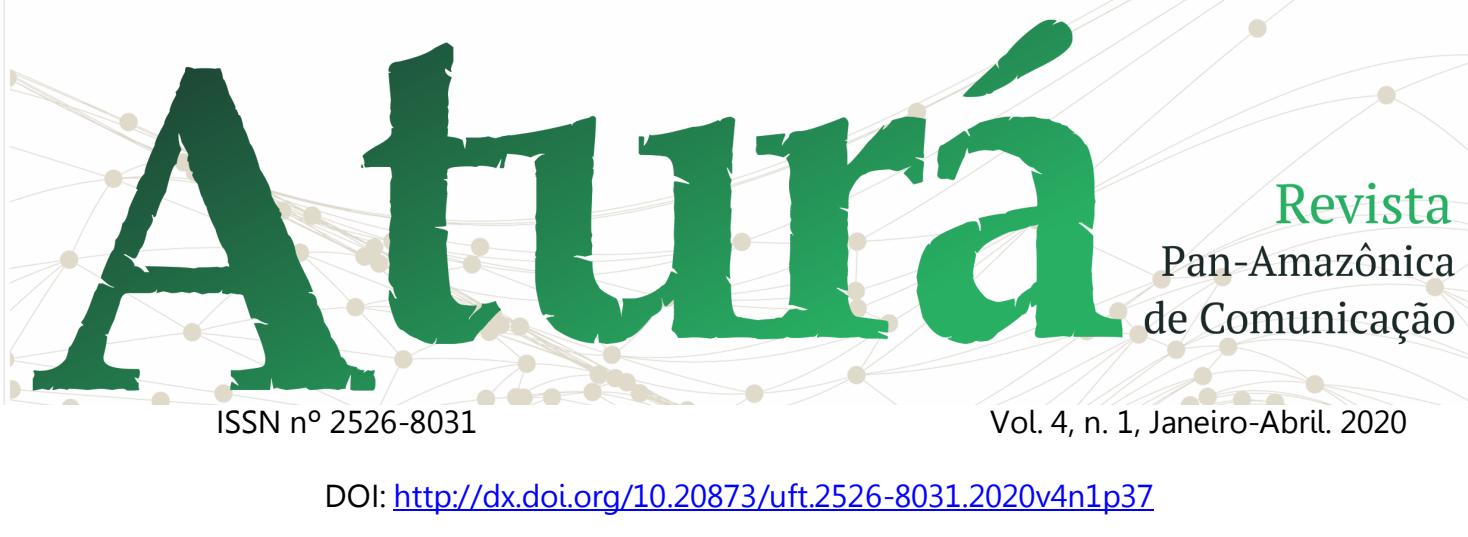

O vídeo-selfie tem 52 segundos ${ }^{5}$. Senhorita Andreza aparece em plano médio (da cintura para cima) fazendo convite para a "social" que ocorreria em sua casa. O tecnomelody É de dentada que elas gostam, da aparelhagem Crocodilo, toca ao fundo. Andreza de Souza tinha cabelos em tom vermelho, usava batom e vestia uma camiseta que deixava à mostra a tatuagem que cobria seu braço, seu ombro e seu peito. No vídeo, ela faz alusão ao público esperado para a festa, diferenciando pelo sexo ("periquitas despintadas" e "caras doidos"), e ao consumo de drogas lícitas e ilícitas que estaria liberado ("chopp", "coca", "erva da Jamaica"). A social era "sem embaçamento", dizia ela, apoiando uma das mãos sob o queixo.

Figura 1 - Print do vídeo de Senhorita Andreza

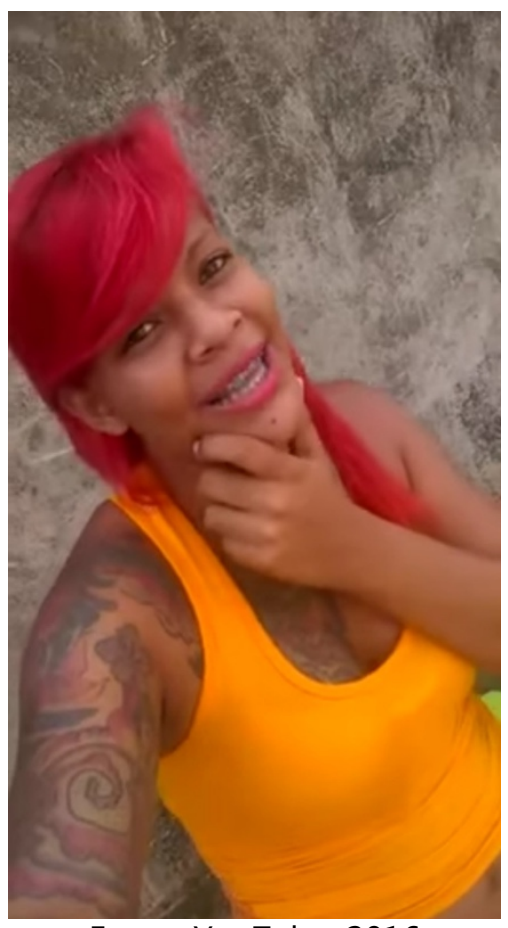

Fonte: YouTube, 2016

A gravação viralizou. Passou a circular em grupos de Whatsapp e nas timelines de redes sociais na internet. $O$ vídeo repercutiu pelas vias do risível e da reprovação. O jeito de falar, o vocabulário usado e a figura de Andreza tornaram-se artifícios para a zoeira e o escárnio. Também o anunciado consumo de drogas virou alvo de julgamento público. A expressão "sem embaçamento" ganhou vida como bordão. Apareceram memes e eventos da festa no Facebook. Uma das

\footnotetext{
${ }^{5}$ Vídeo disponível no link:

https://www.youtube.com/watch?v=jw8j7bXAhxA.
} 


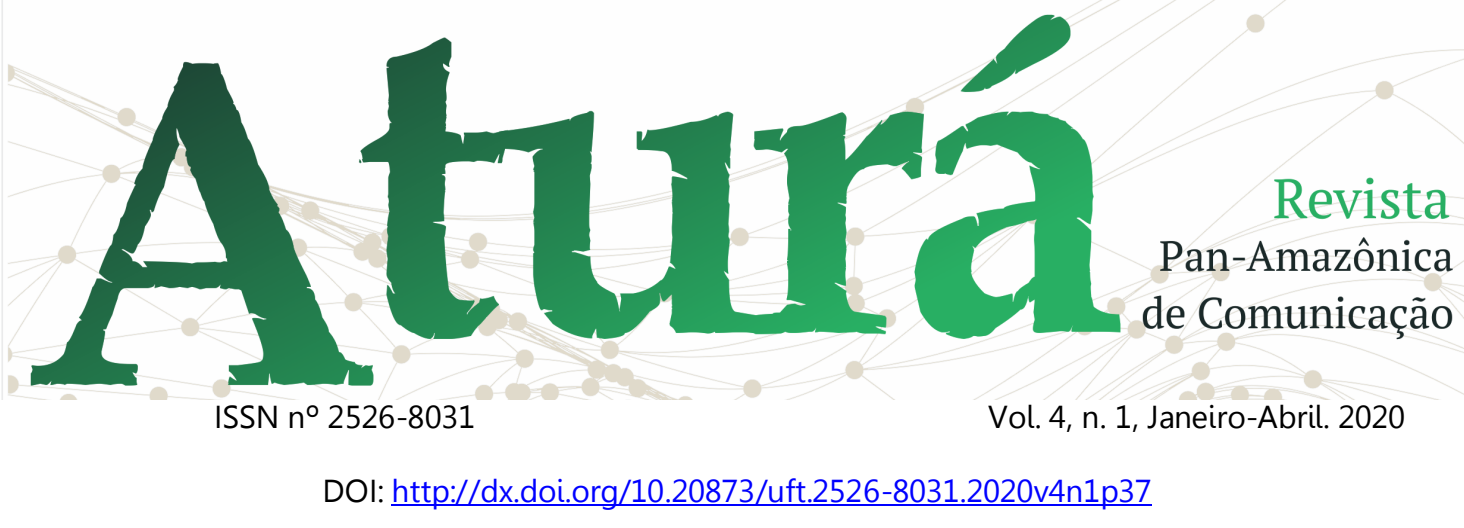

imagens que circulou na época simulava promoção de abadás, com referências a termos usados por Andreza, a sexo e drogas, e associação da festa e de certas áreas da cidade ao crime.

Figura 2 - Meme de abadá para a social de Senhorita Andreza

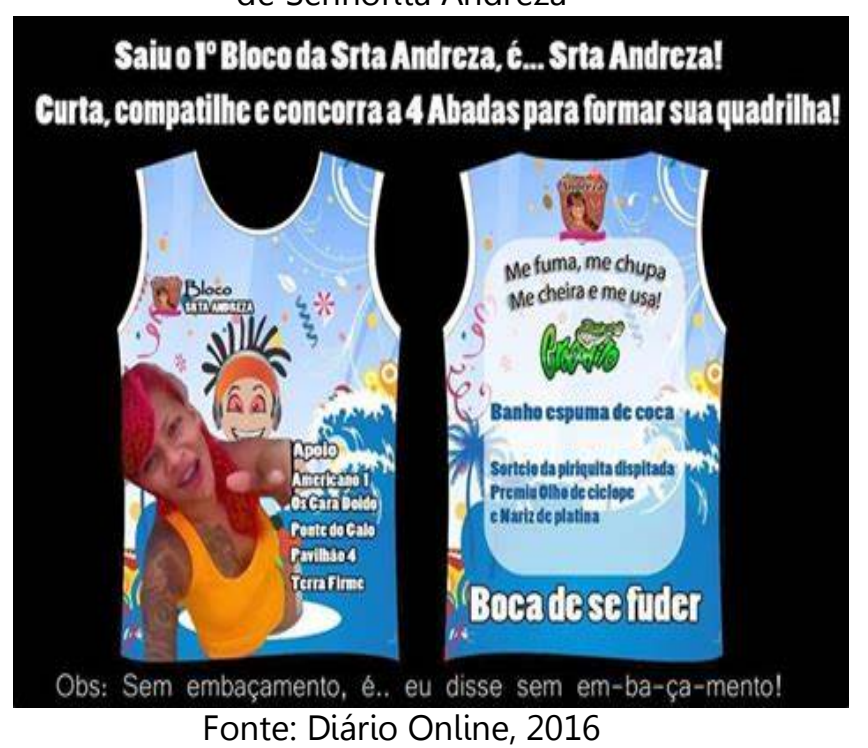

Em geral, vemos nas celebridades uma projeção de nós (MORAES, 2011; SEIXAS, 2018), aquilo que gostaríamos de ser - ou que nos é apresentado como o que deveríamos querer ser. Mas a celebrificação de Senhorita Andreza é construída em sentido contrário, como instauração de um outro com o qual não deveríamos querer parecer, por isso a mediação desse contato se dá pelo riso e pela condenação. A quebra dos padrões de representação de corpos e estilos de vida gera "(...) reação que pode vir travestida de 'humor' ou, menos perigosa, já que mais exposta, como preconceito explícito" (MORAES, 2011, p. 75). No ciberespaço, o controle de padrões da indústria midiática é alargado pela midiatização da diferença, de outros padrões. Só que as hierarquizações permanecem.

O outro que Andreza de Souza representa é um outro histórico, colonial: mulher, negra, periférica. De acordo com Fabiana Moraes (2011), gênero, cor da pele, origem/capital, local de onde se fala e padrão corporal atuam na distribuição desigual de status entre celebridades. Em postagem na página do portal Diário Online no Facebook ${ }^{6}$, de 21 de janeiro de 2016, sobre o vídeo de Andreza, há comentários que citam falta de

\footnotetext{
${ }^{6}$ Postagem disponível no link: https://bit.ly/2mhkN7m.
} 


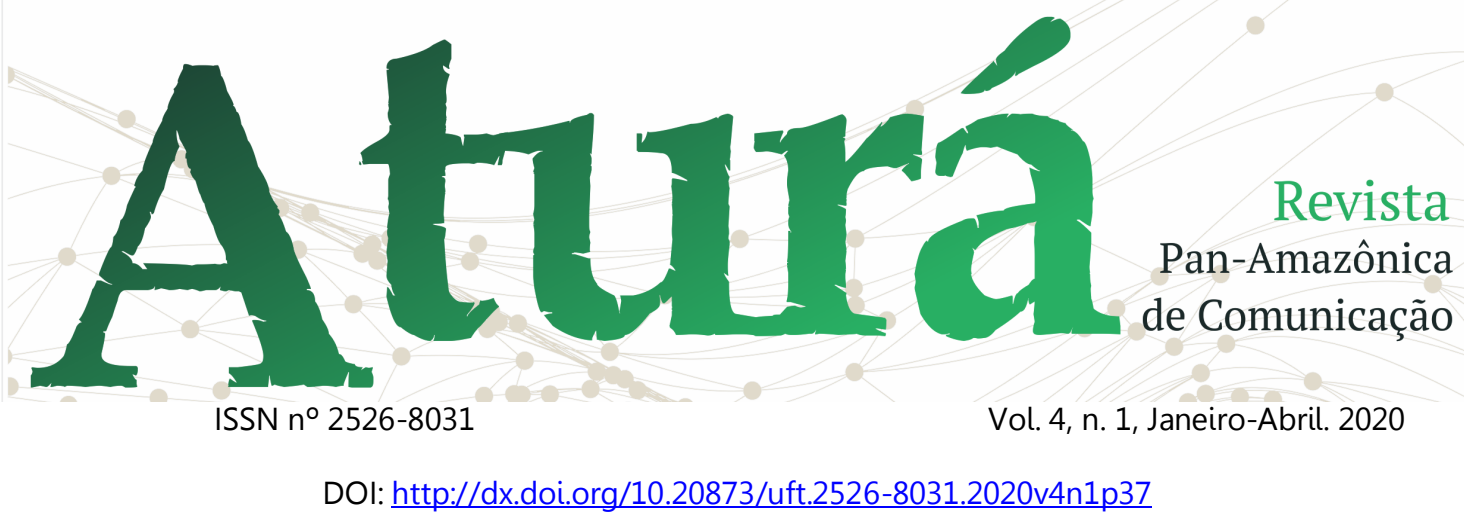

perspectiva, falta de caráter, apologia ao crime, além dos que aparecem carregados de zombaria e dos que criticam a hipocrisia dos julgamentos. Um desses comentários cruza marcadores citados por Moraes, evidenciando o machismo e os preconceitos social e linguístico.

Figura 3 - Comentário em postagem na fanpage do Diário Online

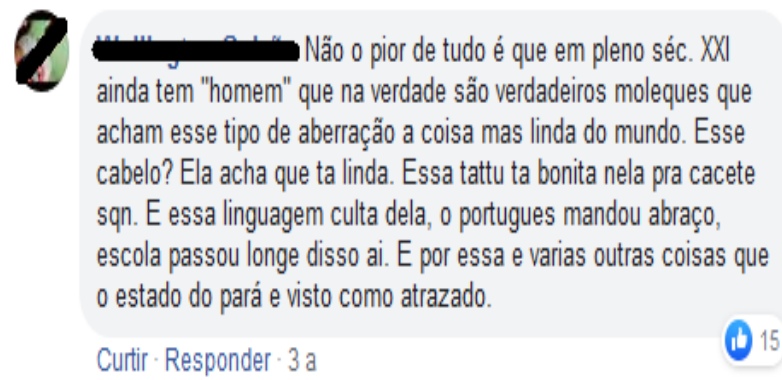

Fonte: Facebook, 2016

A colonialidade do gênero, para María Lugones (2014), configura-se por exercícios de poder concretos que se infiltram em cada aspecto da vida. Um dos meios pelos quais pode ser exposta é o da abjeção estética. Diante da dicotomia hierárquica de gênero, o julgamento do comentário, feito por um homem, sequer é dirigido inicialmente à mulher, e sim a outros homens que porventura vissem alguma beleza em Andreza. Patricia Hill
Collins (2019) sugere que parte da objetificação da mulher está ligada à aparência e que "as afro-americanas sentem a dor de nunca conseguirem viver de acordo com os padrões de beleza vigentes" (p. 167). No comentário, marcas corporais avaliadas como fora do padrão são tomadas como justificadores para a desconsideração daquela vida, para sua desumanização.

Fanon (2008) trata da importância do fenômeno da linguagem na compreensão do racismo e do colonialismo. Para ele, o negro antilhano tornava-se mais branco ao adotar a língua francesa. Tornar-se branco, no caso, significa sair da zona de não-ser. Em uma língua como a portuguesa, há muitas línguas, por isso é possível dizer que o negro brasileiro se aproxima do branco ao adotar a língua definida como padrão e se afasta ao mostrar gírias, sotaques e gestuais de padrões marginais de linguagem. Se "(...) falar é existir absolutamente para o outro" (FANON, 2008, p. 33), nem a fala nem a existência 


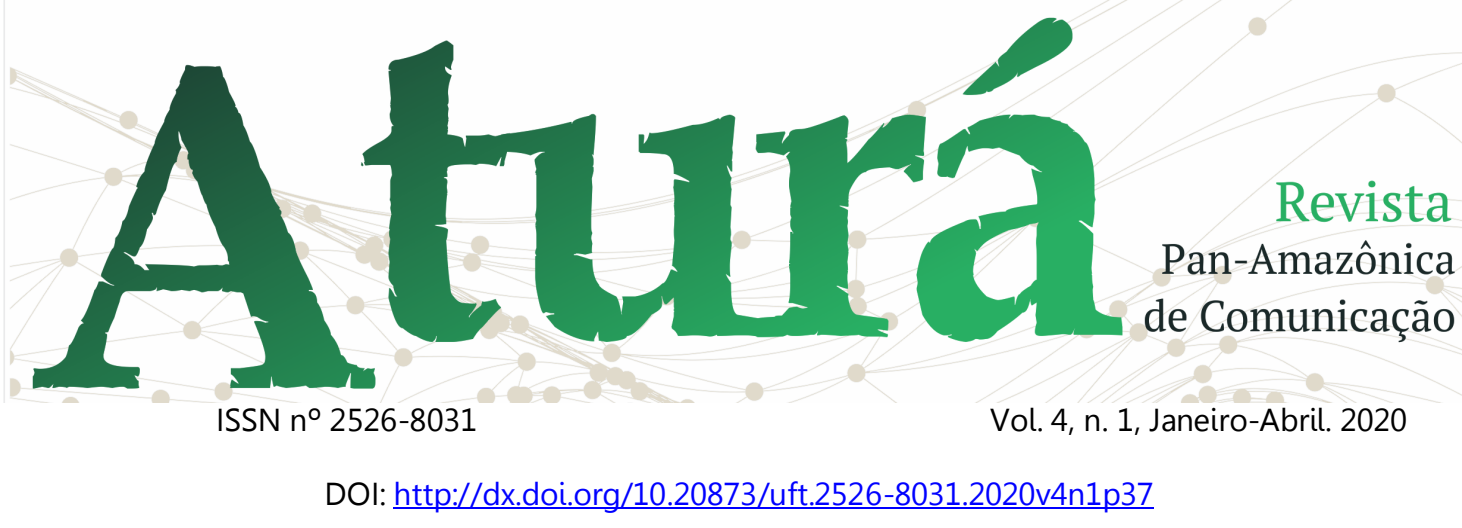

de Andreza parecem se completar, mantendo-a na zona de não-ser.

Em centros urbanos, as zonas de não-ser - no mundo colonizado compartimentado, cortado em dois (FANON, 2005) - costumam estar territorializadas nas periferias. A formação periférica de Belém, em meados do século $X X$, ocorreu, primeiramente, em áreas de baixadas (TRINDADE JÚNIOR, 2016). A partir dos anos 1970, com a expansão urbana para além da Primeira Légua Patrimonial, outras periferias surgiram, entre as quais a Cabanagem, bairro de Senhorita Andreza. O bairro, reconhecido oficialmente em 1996, teve origem na ocupação espontânea da área para moradia, em um tempo em que Belém ficou conhecida como "capital das invasões" (COUTO, 2018).

A Cabanagem e outros bairros periféricos da cidade, conformados como espaços de exclusão e precariedade, acabaram "(...) incorporados às lógicas da economia do crime, sofrendo influência das redes do narcotráfico e das milícias, assim como também sofrem constantemente as ações repressivas do Estado através da polícia" (COUTO, 2018, p. 196). O narcotráfico, como uma rede transnacional no sistema-mundo capitalista, por um lado, usa a população racializada e pobre da periferia de Belém como mão de obra barata - divisão racial do trabalho (QUIJANO, 2005) -, e por outro, torna-se parte da sociabilidade e da cultura cotidiana local. Essa cultura, fruto da colonialidade do poder, acaba criminalizada, atingindo principalmente sujeitos subalternizados como Andreza.

\section{Criminalização e escárnio institucional}

No dia 22 de janeiro de 2016, após a circulação do vídeo que a tornou conhecida na cidade, Senhorita Andreza foi presa pela polícia. O tratamento pejorativo dado a ela na internet ampliouse diante da prisão. Para anunciar a captura de Andreza de Souza, a Superintendência do Sistema Penitenciário do Pará (Susipe) publicou em sua página no Facebook um gif (formato de mídia visual bastante utilizado 


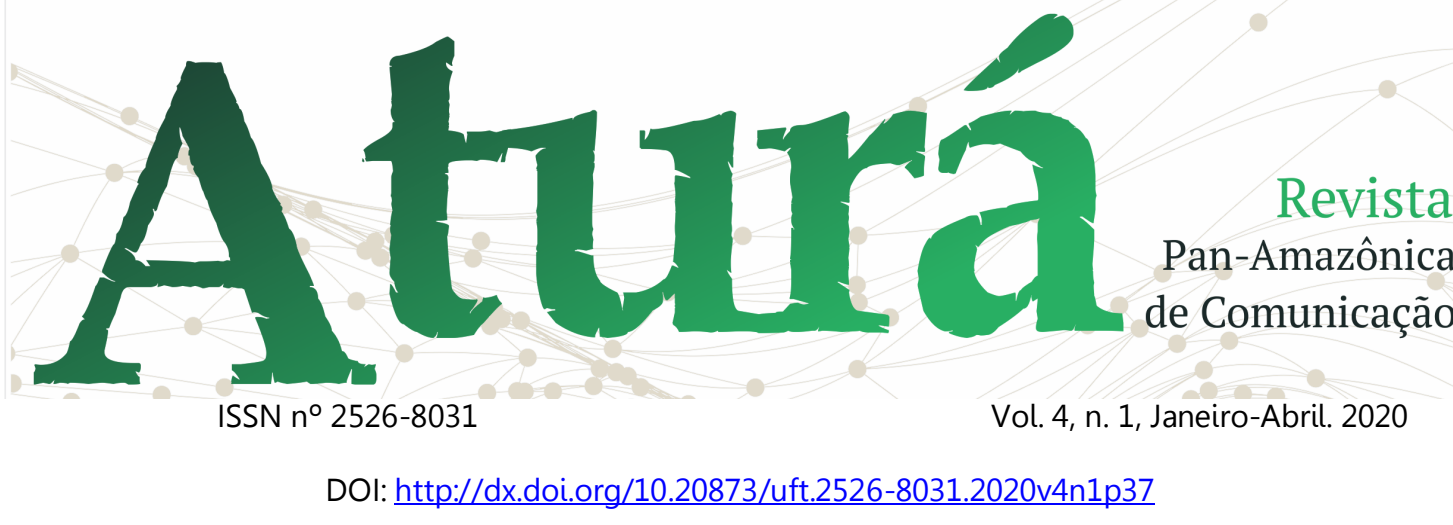

na web, que permite intercalar várias figuras em um só arquivo) contendo três imagens dela. A publicação, além de expor Andreza, zombava da prisão e da "festa cancelada".

Figura 4 - Texto e partes do gif publicados pela Susipe

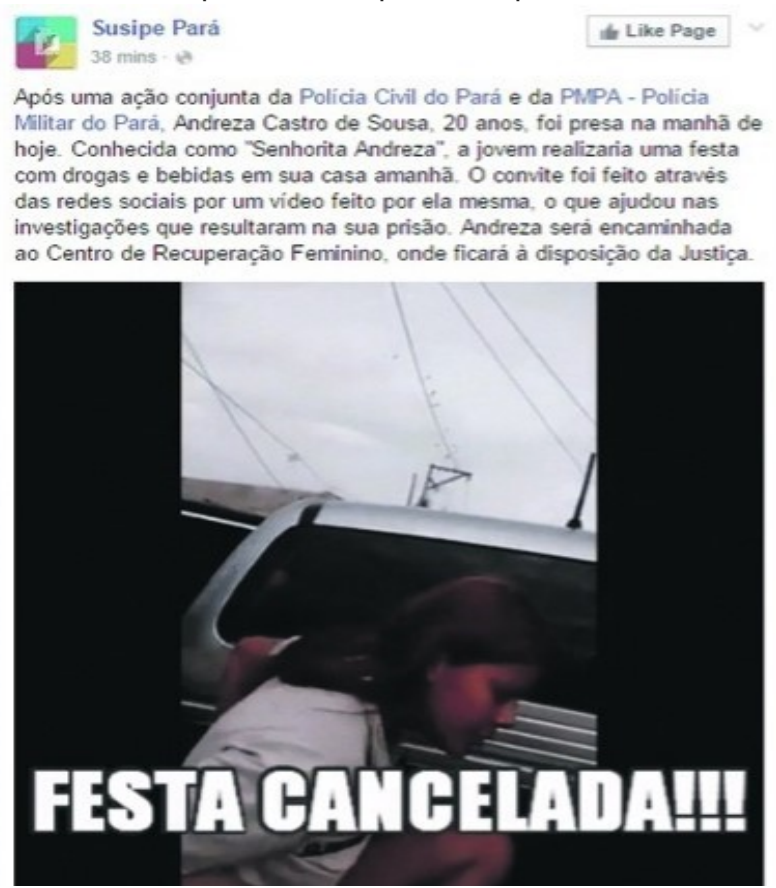

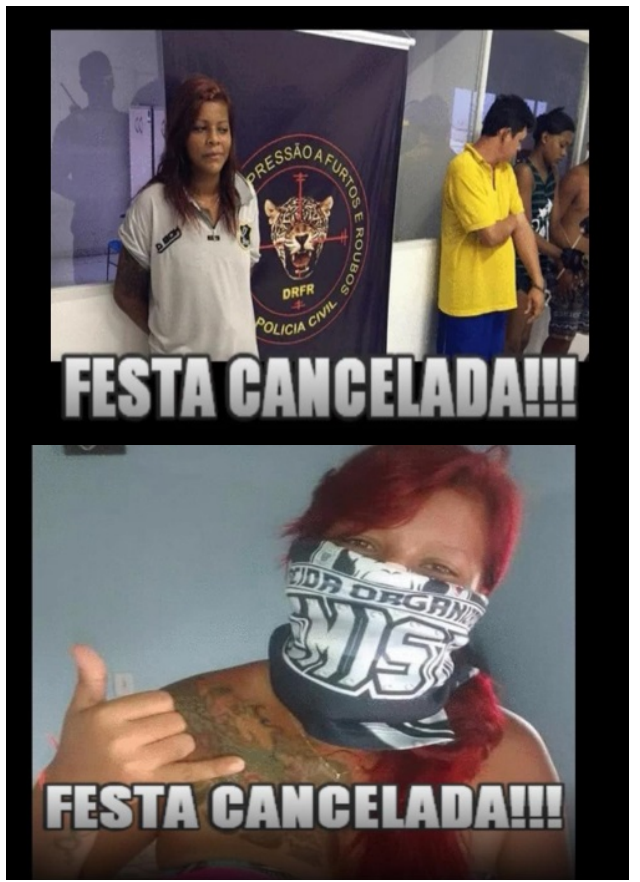

Fonte: Facebook, 2016

Após repercussão negativa nas redes sociais, com questionamentos à forma como Andreza tinha sido tratada pelo órgão governamental, a Susipe decidiu apagar a postagem com o gif e tentou se retratar por meio de uma nota de esclarecimento ${ }^{7}$. A nota, no entanto, não admite a humilhação pela qual a instituição fez Andreza passar, e ainda utiliza o termo racista "denegrir".

Figura 5 - Nota de esclarecimento da Susipe

\footnotetext{
7 Postagem disponível no link: https://bit.ly/2nSfSKJ.
} 


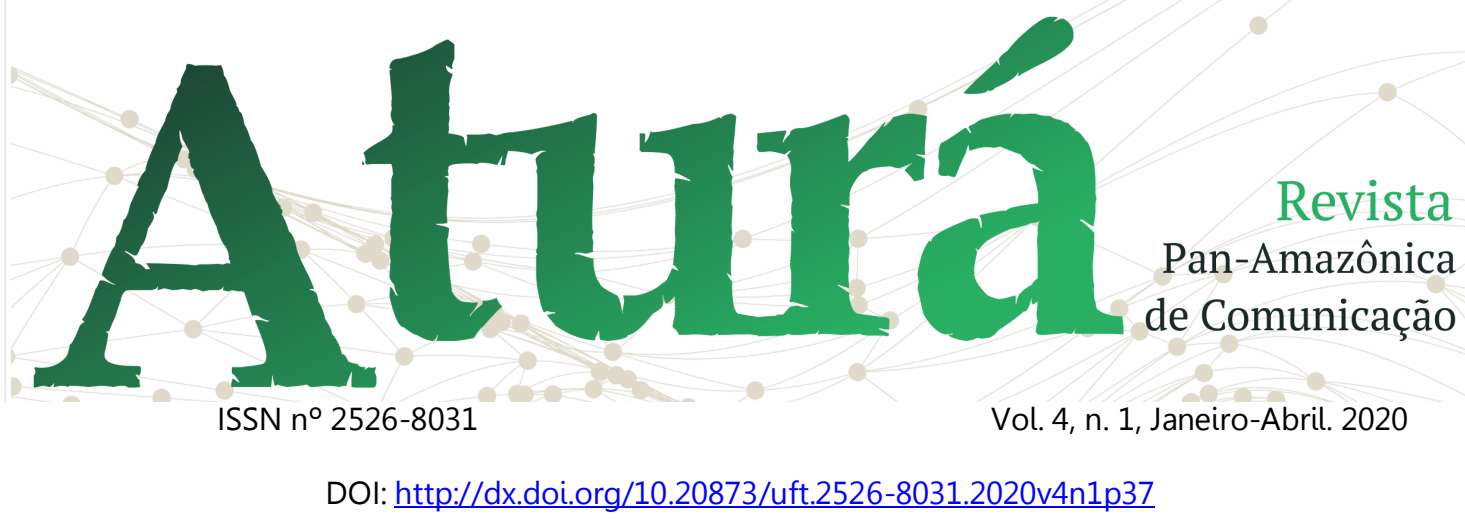

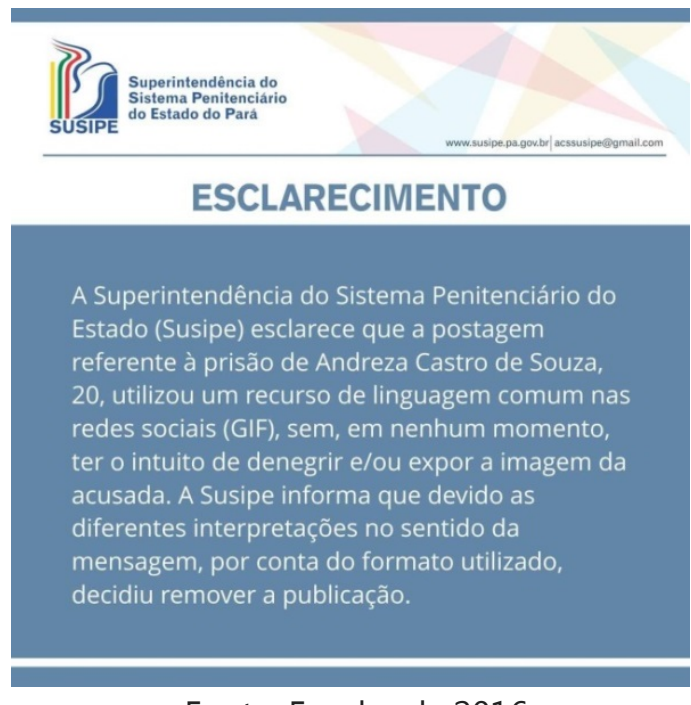

Fonte: Facebook, 2016

A ideia de raça, para Quijano (2014), é uma invenção do sistema colonial que surgiu com o objetivo de hierarquizar os seres humanos. Essa divisão racial, que classifica os superiores e os inferiores pela cor da pele, atravessa séculos e é constantemente atualizada na América Latina por grupos sociais que controlam as instituições e acreditam ser herdeiros do poder colonial. "O Estado-nação é estabelecido precisamente pelos que herdam os privilégios do poder colonial. Ou seja, como imposição de seus interesses sobre os interesses de todos os demais setores e, em primeiro lugar, sobre os de 'índios' e 'negros'" (QUIJANO, 2014, p. 769, tradução livre).

O desrespeito sofrido por Andreza de Souza diante da postura da Susipe, que tem a missão de "possibilitar tratamento humano aos que cumprem pena em estabelecimentos prisionais' ${ }^{8}$, expôs 0 racismo institucional existente. De acordo com Marco Antonio Silva (2017), o racismo institucional consiste "no fracasso das instituições e organizações em prover um serviço profissional e adequado às pessoas em virtude de sua cor, cultura, origem racial ou étnica" (2017, p. 6). Essa forma de racismo se expressa de diversas maneiras: na falta de políticas públicas e no acesso desigual a bens e serviços por parte de pessoas negras e, em caráter simbólico, "na representação do negro na sociedade como violento, lascivo e agressivo" (BORGES, 2019, p. 58).

Com a prisão e o gif, os grupos de poder coloniais, representados por um órgão do Estado, reforçam sobre

\footnotetext{
8 Disponível no site da Susipe: https://bit.ly/2nSy72u.
} 


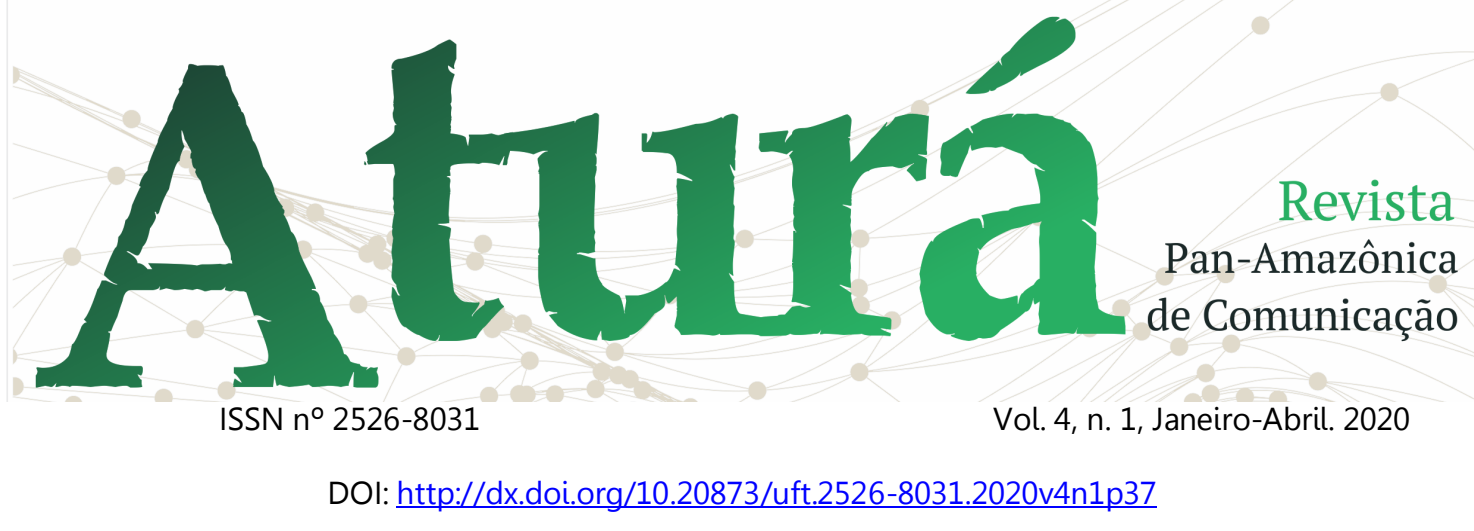

Senhorita Andreza uma imagem de controle, a de mulher criminosa. As imagens de controle, segundo Hill Collins (2019), guardam contornos da objetificação da mulher, são imagens forjadas para naturalizar sexismo, racismo, pobreza e outras formas de injustiça social. Essas imagens posicionam as mulheres negras como outro, com "características negativas opostas e inferiores àquelas reservadas aos brancos" (HILL COLLINS, 2019, p. 166).

Juliana Borges (2019) considera que o encarceramento de mulheres negras está atrelado ao sexismo e ao racismo institucional presentes na controversa política do Estado de guerra às drogas. "Diversas estudiosas e intelectuais têm apontado a chamada 'guerra às drogas' como um fator central no aumento exponencial do encarceramento e como discurso que impulsiona e sustenta a manutenção de desigualdades baseadas em hierarquias raciais" (BORGES, 2019, p. 101). Esses impactos e consequências, segundo Borges, são ainda mais sentidos pelas mulheres.

De acordo com dados do Levantamento Nacional de Informações Penitenciárias Infopen Mulheres (2017), em junho de 2016, a população prisional feminina localizada no Pará era de 740 mulheres. Desse total, $89 \%$ eram mulheres negras - percentual maior que a média nacional. O motivo da prisão de Andreza de Souza, envolvimento com o tráfico de drogas, correspondia a $63 \%$ dos crimes cometidos pela população prisional feminina em território paraense.

A detenção de Senhorita Andreza repercutiu nos noticiários. O programa policialesco Metendo Bronca, da RBA TV9 veiculou reportagem sobre $O$ caso. Durante o programa, o apresentador Joaquim Campos - que seria eleito vereador, o segundo mais votado, na mesma eleição disputada por Andreza chama a jovem de "vagabunda" e explica que, no vídeo que viralizou, ela "convoca outras vagabundas para a festa". Campos

\footnotetext{
9 Vídeo disponível no link: https://bit.ly/2moqW10.
} 


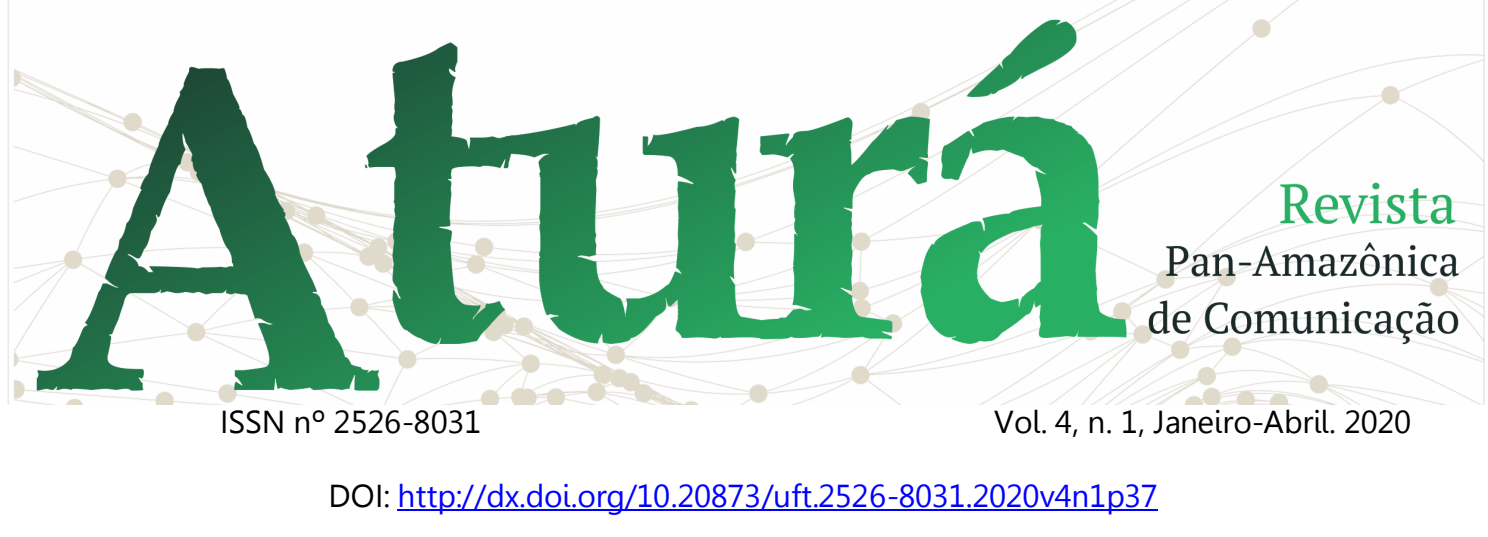

passa então a definir o que, em sua opinião, seria uma mulher de verdade: aquela que é "mãe" e "geradora de vidas". Já Andreza ele descreve como alguém que "não serve para nada" e "tem um útero que só vai reproduzir imundice".

$\mathrm{Na}$ fala do apresentador, Senhorita Andreza é colocada na condição de não mulher. Ela não corresponde à imagem do que, na concepção patriarcal de seu juiz midiático, significa ser do gênero feminino: mãe, geradora de vidas. Ao contrário, Andreza servia para nada e, caso viesse a ter filhos, não iria gerar um ser humano, mas algo imundo - na época, ela já era mãe. Esse vídeo, disponível no Youtube e visto por mais de 100 mil pessoas, atualiza um discurso racista e sexista que expulsa a mulher negra para fora da humanidade.

Lugones (2014) considera a dicotomia hierárquica entre humano e não humano como ponto central da modernidade colonial. Essa categorização virou ferramenta normativa para condenar colonizados (LUGONES, 2014). A prática colonial aparece nos modos como a
Susipe e o programa Metendo Bronca tratam a prisão de Andreza. A posição de inferioridade delegada à jovem é reiterada nos comentários do vídeo, que materializam os ecos da narrativa desumanizante de Joaquim Campos no imaginário social. Como, na internet, as visualizações atravessam tempos distintos, os comentários não são apenas relacionados à prisão, mas também ao assassinato de Senhorita Andreza, ocorrido no ano seguinte.

Figura 6 - Comentários no Youtube

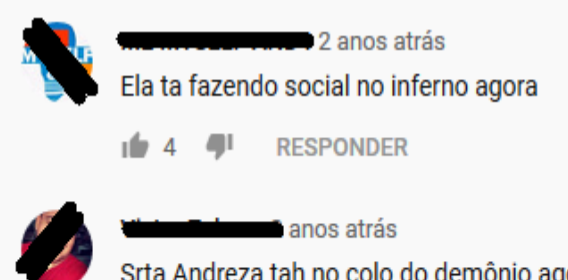

Srta Andreza tah no colo do demônio agora! foi tarde saco de bosta!

It 6 I RESPONDER

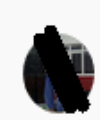

2 anos atrás

sera que 0 capeta embaçou com a chegada dela? I 3 I RESPONDER

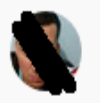

Caiu a casa da vagabunda! Huahuahuahuahuahua! I I RESPONDER

Fonte: Youtube, 2016

Andreza de Souza passou 25 dias na prisão, mas o efeito de desumanização 


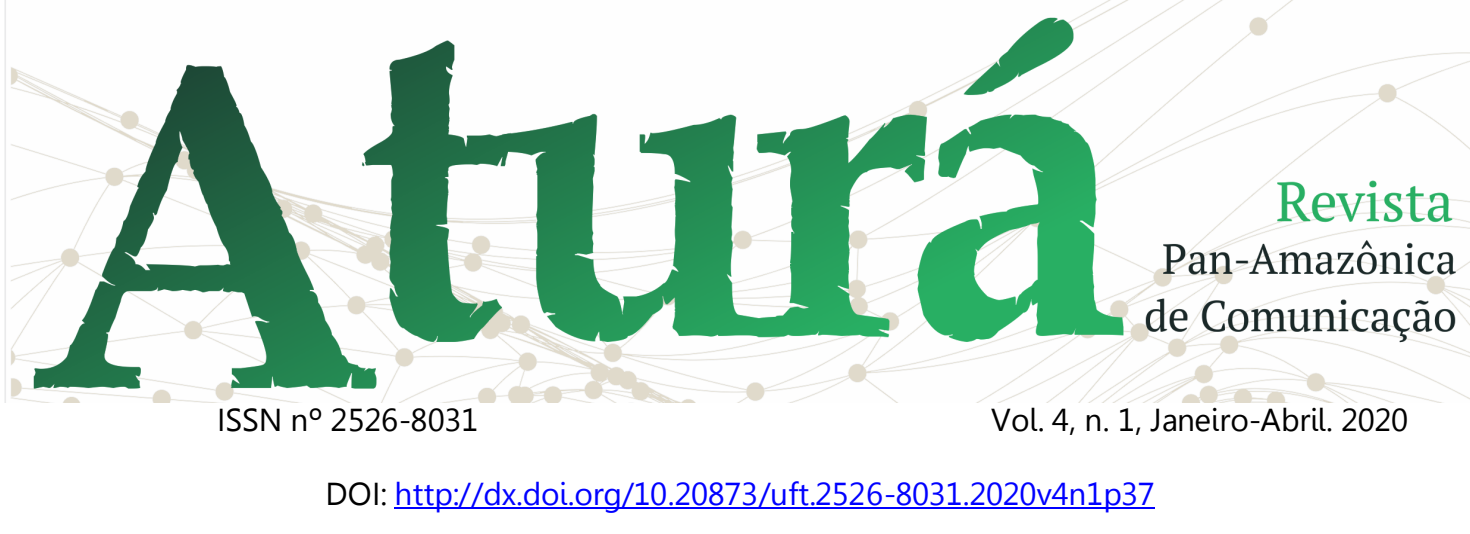

acompanha quem volta à liberdade. $\mathrm{O}$ cárcere e o pós-encarceramento "significam a morte social desses indivíduos negros e negras que, dificilmente, por conta do estigma social, terão restituído o seu status, já maculado pela opressão racial em todos os campos da vida, de cidadania ou possibilidade de alcançá-la" (BORGES, 2019, p. 22). Apesar da condição continuada da morte social, Andreza ainda tentaria resistir, recuperar a dignidade ferida.

\section{Da social à política partidária}

Mulheres negras periféricas como Senhorita Andreza não são corpos que ocupam com frequência os quadros da política partidária e outras instâncias de poder, dominadas por homens brancos. Para Sueli Carneiro (2015), falar da relação entre mulher negra e poder, por praticamente inexistir, é falar do ausente. Contrariando essa ausência histórica, Andreza de Souza, foi convidada a integrar

10 Reportagem disponível no link: https://bit.ly/2mWAOQH. a União da Juventude Socialista (UJS), que faz parte do Partido Comunista do Brasil (PCdoB), e decidiu se candidatar ao cargo de vereadora de Belém nas eleições de 2016.

"Eles fizeram o convite e eu quero mudar de vida. Por que o que eu passei no CRF [Centro de Reeducação Feminino] eu não quero passar nunca mais. E eu não quero que ninguém esteja lá. E, como aqui na UJS é uma oportunidade para estar ajudando vários jovens, eu aceitei", explicou Andreza, em entrevista ao Portal Outros400 publicada três meses após a sua prisão ${ }^{10}$, uma das poucas vezes em que foi ouvida pela imprensa sem ser desumanizada, em que teve restituída a palavra. Nesse trecho da fala de Senhorita Andreza, a política aparece ligada a um projeto pessoal e coletivo: a partir da militância partidária, ela via possibilidade de transformar a própria condição de vida e ajudar outros jovens.

No vídeo que fez para a campanha eleitoral ${ }^{11}$, Andreza de Souza se apresenta

\footnotetext{
11 Vídeo disponível no link: https://bit.ly/2nWMwuo.
} 


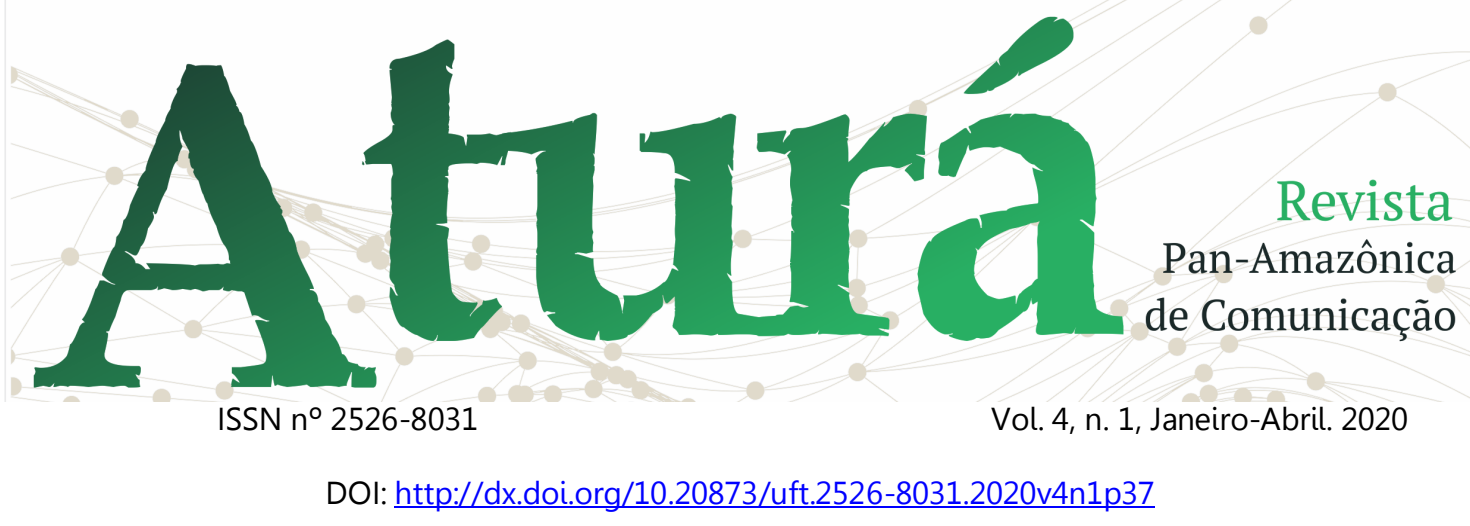

assim: "Sou a Senhorita Andreza, juntos venceremos o ódio e o preconceito... $e$ garantir o direito da juventude da periferia. Vem com a gente! 65.100... embaçamento". Em diálogo com sua história de vida, ela reitera a preocupação com a juventude como bandeira política e se coloca contra o ódio e o preconceito. Senhorita Andreza ainda aproveita o bordão "sem embaçamento" para marcar seu número de candidata, ressignificando com irreverência a linguagem que havia sido julgada e ridicularizada.

A força das colonialidades, no entanto, persiste. Quando a précandidatura de Andreza foi anunciada pela mídia, houve muitas críticas e alguns apoios. Em uma postagem na página do Diário Online no Facebook ${ }^{12}$, sobre a matéria "Senhorita Andreza quer ser vereadora", alguns comentários acusam a jovem de estar envolvida com o tráfico de drogas e a criminalidade, tratando como inaceitável a participação dela nas eleições. Há também comentários que consideram a baixa escolaridade como uma condição que não qualificaria Andreza para exercer um cargo político.

Figura 7 - Comentários em postagem na fanpage do Diário Online

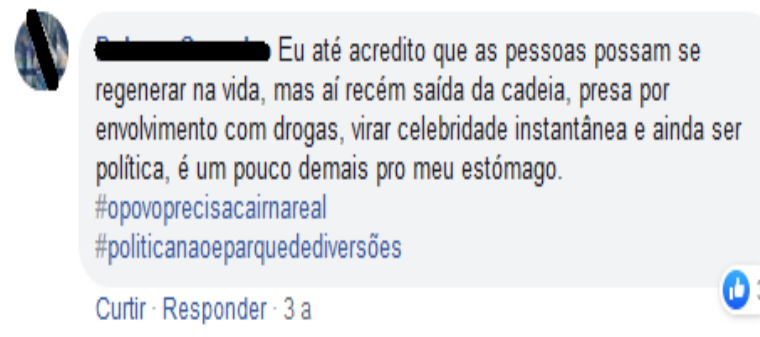

Talvez se fizesse uma nova lei como por exemplo: para poder se canditadar, no minimo a pessoa teria q ter ensino superior em algo como direito ou medicina... Algo assim... Posgraduado em administração... Algo q pudesse acrescentar no poder governamental. Eu particularmente pesquiso muito bem sobre a pessoa antes de votar!

Curtir - Responder - 3 a

E muita sacanagem com a nossa cara mesmo ! Enquanto muitos universitários e pessoas qualificadas estão ai na Batalha atrás de um emprego essa ai que logo cargo político porque será né?

Curtir - Responder $\cdot 3 \mathrm{a} \cdot$ Editado

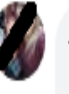

Meu deus td ta perdido mesmo Belém pode ter social td dia gente imagina um reunião ki ela promova caraca muita bebida e droga só os drogado vão vota nela ....senhor nos guarda Curtir-Responder - 3 a

Fonte: Facebook, 2016

Os comentários nas redes sociais na internet são uma extensão do imaginário racista e classista da sociedade

\footnotetext{
12 Postagem disponível no link: https://bit.ly/2oEqgpN.
} 


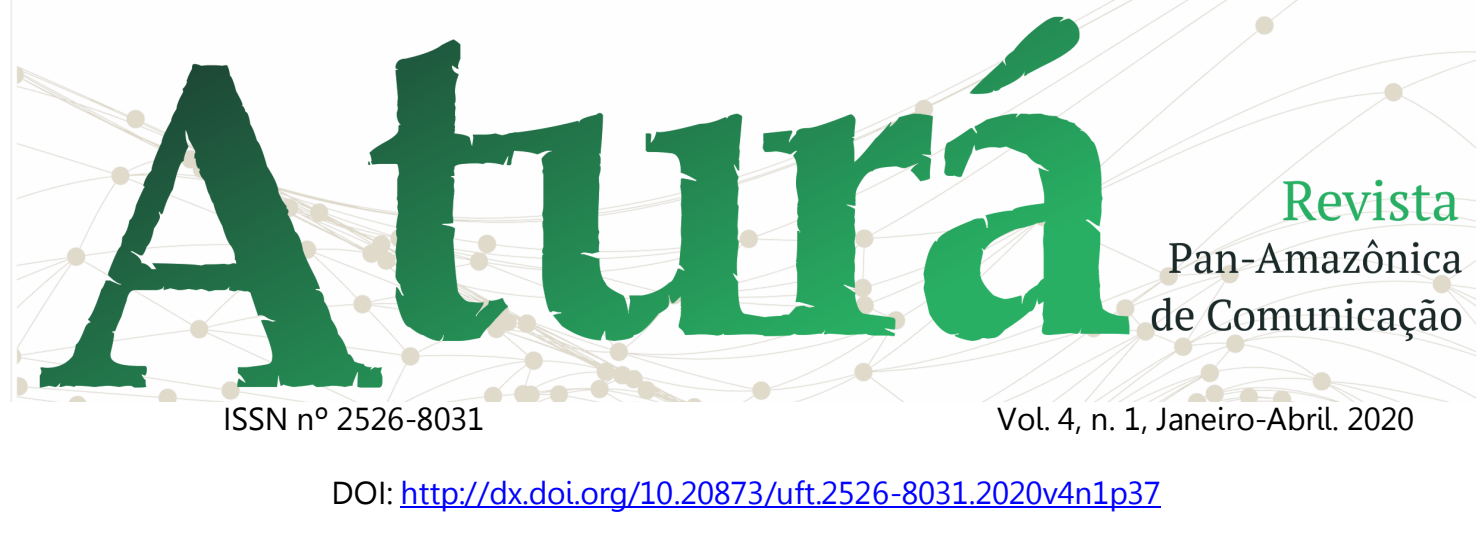

brasileira. De acordo com Lélia Gonzalez (2018, p. 191), "o racismo se constitui como a sintomática que caracteriza a neurose cultural brasileira". Como articulação ideológica de exclusão, o racismo se instaura em um conjunto de práticas que determina a posição de negros e não brancos nas estruturas de produção e reprodução racial (e sexual) de trabalho no capitalismo. São esses grupos sociais racializados que acabam explorados pelo sistema - portanto desumanizados.

Gonzalez (2018) retoma a história do Brasil para mostrar como as mulheres negras foram violentamente subalternizadas no período da escravização, e que ainda hoje esse processo traz consequências em suas trajetórias socioculturais. No período colonial, em que os sujeitos negros foram trazidos do continente africano para terras brasileiras como mão de obra escrava, as mulheres tiveram que suportar, além do peso da violência física, o da exploração sexual. Na Casa Grande, elas foram as responsáveis pela vida doméstica e pelo cuidado dos filhos das sinhás.

As mulheres negras, então, foram enquadradas em estereótipos racistas e sexistas, entre os quais a "mulata tipo exportação", mulher negra amplamente estigmatizada no carnaval, que tem o seu corpo "disponível" para a exploração sexual, tal qual ocorria no período da escravização. Ou a "mãe preta", aquela mulher "passiva", cuidadora do lar e das crianças da casa, a quem recai todo o peso da exploração doméstica. "Quanto à doméstica, ela nada mais é do que a mucama permitida, a da prestação de bens e serviços, ou seja, o burro de carga que carrega sua família e a dos outros nas costas" (GONZALEZ, 2018, p. 197).

Esses estereótipos - que equivalem às imagens de controle teorizadas por Hill Collins - recaem sobre as mulheres negras, mesmo que elas tenham ascendido socialmente, por conta do marcador que Gonzalez (2018) nomeia de culpabilidade branca. Assim, não é incomum mulheres negras serem "confundidas" em seus ambientes de 


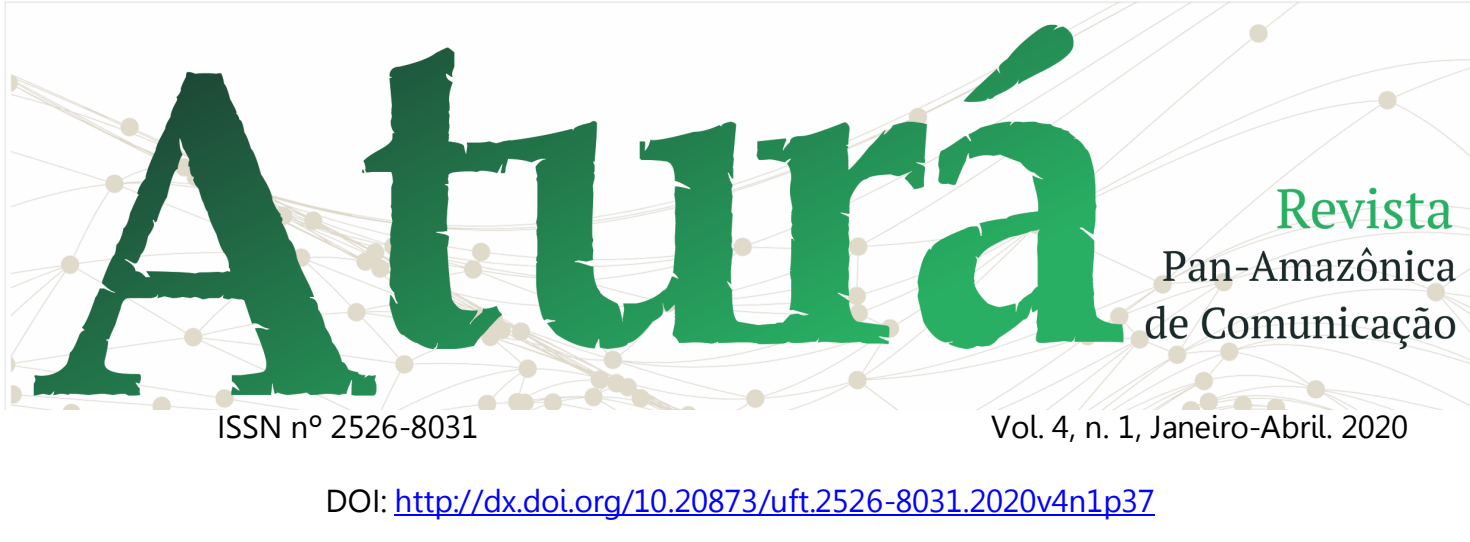

trabalho com faxineiras ou empregadas domésticas. Aos olhos dos brancos, é esse - lugar que lhes cabe. Tentativas de deslocamento dessa posição costumam encontrar barreiras.

\begin{abstract}
Mas é justamente aquela negra anônima, habitante da periferia, nas baixadas da vida, quem sofre mais tragicamente os efeitos da terrível culpabilidade branca. Exatamente porque é ela que sobrevive na base da prestação de serviços, segurando a barra familiar praticamente sozinha. Isto porque seu homem, seus irmãos ou seus filhos são objeto de perseguição policial sistemática (esquadrões da morte "mãos brancas" estão aí matando negros à vontade; observa-se que são negros jovens, com menos de trinta anos. Por outro lado, que se veja quem é a maioria da população carcerária deste país). (GONZALEZ, 2018, p. 199)
\end{abstract}

No caso de Senhorita Andreza, ela própria enfrentou a perseguição policial e - cárcere. As colonialidades que influenciaram as mortes sociais de Andreza também faziam dela alguém fora do lugar na disputa política. A ausência de mulheres negras nos espaços decisórios é reiterada pelos dados. De acordo com o site Gênero e Número ${ }^{13}$, em 2014, foram eleitas dez mulheres negras e nenhuma indígena para a Câmara Federal, o que não representava nem $2 \%$ dos 513 deputados. $\mathrm{Na}$ eleição de 2018 , o quantitativo passou para 13 mulheres negras e uma indígena, $2,7 \%$ do total. Na eleição em que pleiteou, sem sucesso, uma cadeira na Câmara Municipal de Belém, Andreza de Souza recebeu 789 votos. Nenhuma mulher negra foi eleita vereadora para aquela legislatura.

Posicionar-se fora do lugar, fazer-se presente em um espaço em que mulheres negras costumam estar ausentes, era uma forma de Andreza mobilizar algum reconhecimento no processo de visibilização pública, até então limitado. A opressão colonial não exerce domínio completo, há sempre brechas com respostas e resistências por parte dos sujeitos que habitam um lócus fraturado marcado pela tensão entre a dicotomia hierárquica e a subjetividade ativa do colonizado (LUGONES, 2014). E, como sugere Lugones (2014), tratando

\footnotetext{
13 Informações disponíveis no link: https://bit.ly/2QpFWt8.
} 


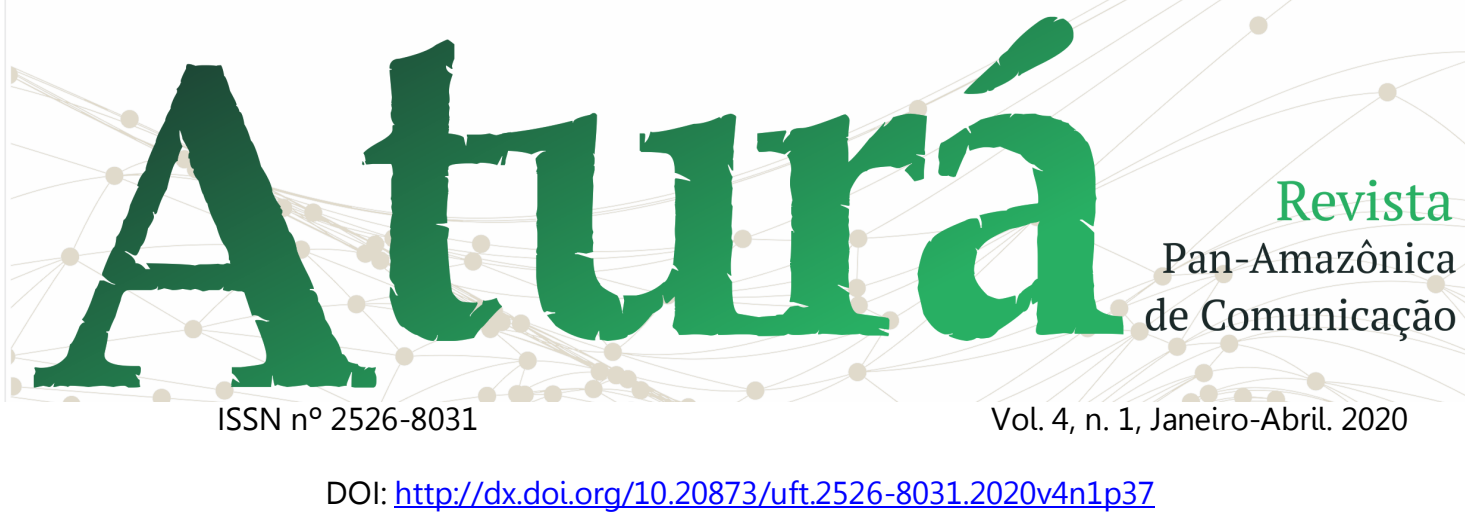

especificamente da colonialidade do gênero, é em comunidade que esse resistir aparece. No caso de Andreza, na integração à discussão coletiva de um projeto político.

Para Hill Collins (2019), a autodefinição é um dos pontos importantes no processo de consciência e resistência. "Quando a sobrevivência da mulher negra está em jogo, criar autodefinições independentes é essencial" (HILL COLLINS, 2019, p. 203). Ao falar como candidata, ao impor sua presença indesejada, Andreza questionava, ainda que parcialmente, as imagens de controle em que the haviam enquadrado e a autoridade de quem assumia o poder de definir por ela seu lugar no mundo. Mas essa busca por visibilidade, por uma imagem que garantisse à Senhorita Andreza humanidade, meses após a derrota eleitoral, acabou interrompida pelo caminho.

\section{Necropolítica e visibilização desumanizante}

Às vésperas do Natal de 2016, o companheiro de Senhorita Andreza, Huanderson Ferreira Ramos, foi assassinado com dez tiros. Quase quatro meses depois, na noite de 13 de abril de 2017, foi a vez de Andreza. Ela caminhava pelo bairro da Cabanagem ao lado de uma prima quando dois homens apareceram em uma motocicleta. Um dos homens desceu e avançou na direção de Andreza. Ela tentou fugir. Correu até um bar, mas foi executada com cinco tiros. Deixou uma filha ainda criança. $O P C$ doB, em nota ${ }^{14}$, lembrou que a juventude da periferia estava entregue à violência e ao extermínio promovidos pelo tráfico e pelas milícias, "que muitas vezes são associados". O crime não foi solucionado.

O Atlas da Violência 2018 - com base em dados de 2016 - apontou Belém como a capital com maior taxa de mortes violentas do Brasil. Andreza Ariani Castro de Souza foi uma das vidas atingidas pelo avanço do que Achille Mbembe (2018) chama de necropolítica, essas formas contemporâneas que subjugam a vida ao

\footnotetext{
${ }^{14}$ Nota disponível no link: https://bit.ly/2n7O5FR.
} 


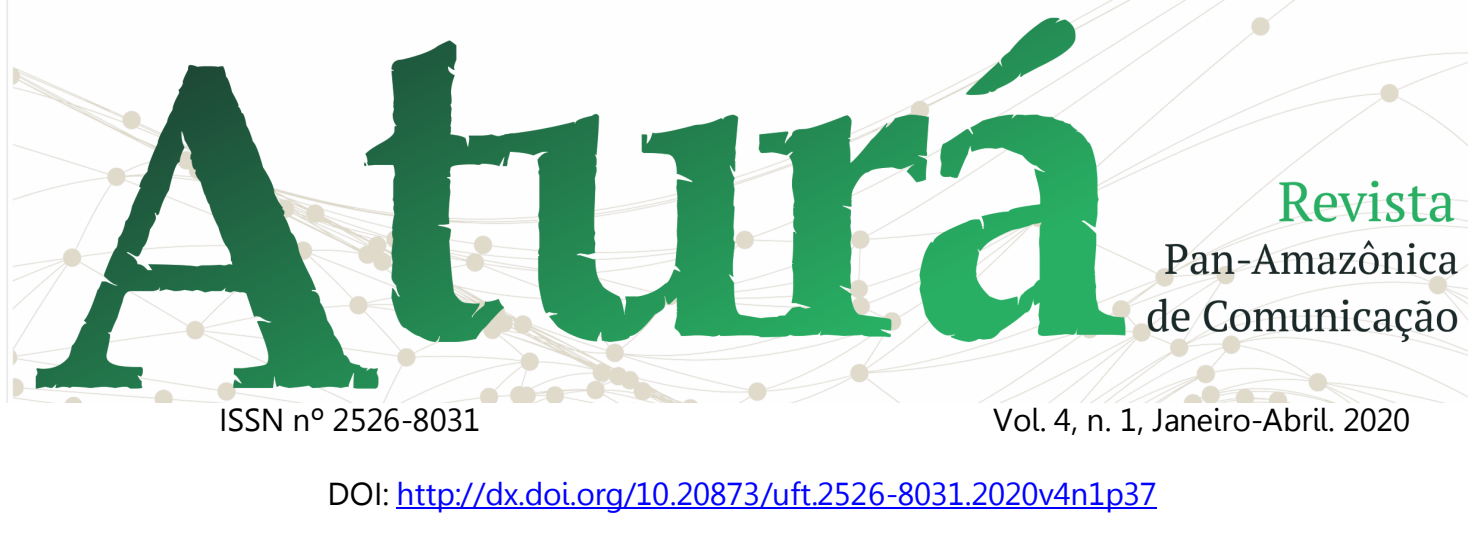

poder da morte. Colonialidades como o racismo regulam a distribuição da morte, que atinge sobretudo a juventude racializada das periferias urbanas. No mundo colonial compartimentado, a periferia é a cidade do colonizado: "(...) um lugar mal afamado, povoado de homens mal afamados. Ali, nasce-se em qualquer lugar, de qualquer maneira. Morre-se em qualquer lugar, de qualquer coisa" (FANON, 2005, p. 56).

A população territorializada nas margens das cidades é considerada suspeita, perigosa e ameaçadora (COUTO, 2018), por isso matável. Em casos como o de Senhorita Andreza, como diz Nelson Maldonado-Torres (2007, p. 154, tradução livre) "(...) a suposta inferioridade é convertida em dispensabilidade". Como um damné, que não só está condenado a não ser livre, mas a morrer antes do tempo (MALDONADO-TORRES, 2007). narcotráfico tem papel preponderante nas estruturas de poder e de conflitos sociais geradoras dos frequentes homicídios em

\footnotetext{
15 Vídeo disponível no link: https://bit.ly/2ovUDyr.
}

Belém (COUTO, 2018). Também são decisivos a prática de extermínio das milícias e o combate das forças do Estado ao narcotráfico proclamado como "guerra legítima" - mas contra quem essa guerra seletiva avança?

A morte física de Andreza não estancou suas mortes sociais. Se, em vida, era-lhe interditada a existência plena, por que, ao encontrar a morte, seria ela considerada digna de luto? As tentativas de enlutamento público foram questionadas. Diante do pedido de um minuto de silêncio na Câmara Municipal, onde Andreza havia pleiteado uma cadeira, o vereador Sargento Silvano (PSD) reagiu: "E nós não podemos admitir essa casa da sociedade fazer um minuto de silêncio pra uma mulher que viveu no crime"15. Em postagem feita pelo Diário Online em sua página no Facebook no dia do assassinato ${ }^{16}$, apareceu o comentário a seguir.

Figura 8 - Comentário em postagem na fanpage do Diário Online

16 Postagem disponível no link: https://bit.ly/2nVh9Aq. 


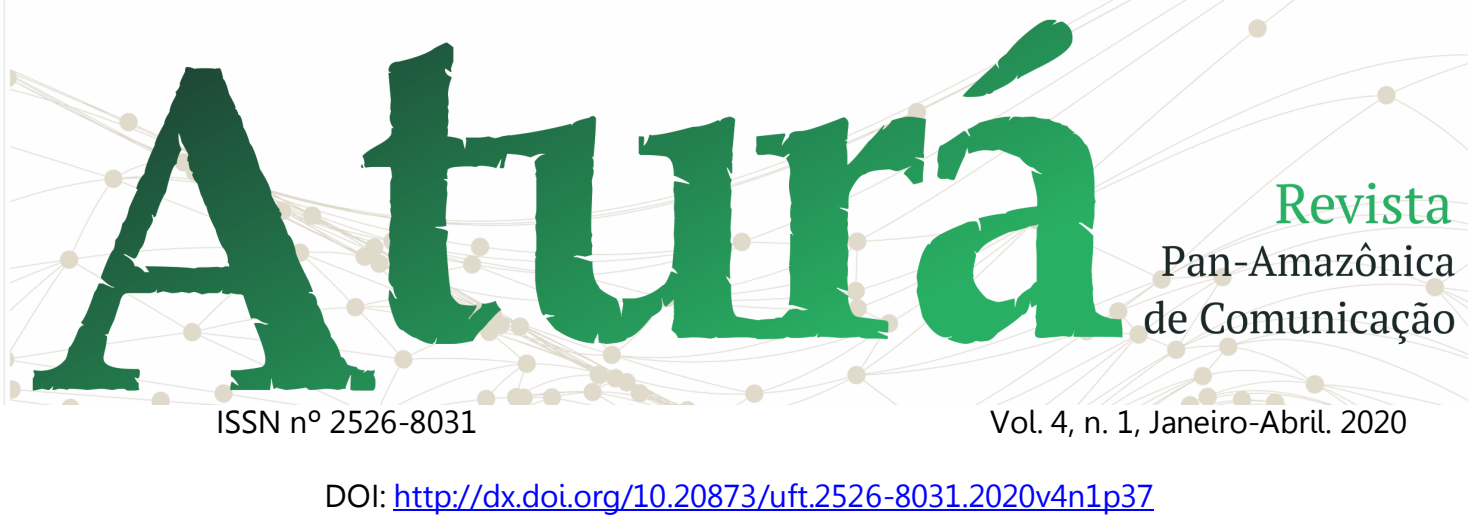

Embora os últimos meses da vida

Engraçado... Quando um PAl ( MÃ̃E) de FAMílIA, TRARABALHADOR, morrem em um assalto ou de bala perdida. Não vejo as redes sociais (pessoas) se importarem com isso... Na realidade quem é ser humano?

Curtir - Responder - $2 \mathrm{a} \cdot$ Editado

Fonte: Facebook, 2016

Quem é ser humano? É essa distinção que a colonialidade organiza. Cada morte social de Andreza a empurra para a zona de não-ser. Mas o faz de modos diferentes, como indica a análise construída neste artigo. As colonialidades que atravessam a visibilização de Senhorita Andreza se apresentam, durante a viralização do vídeo, na forma principalmente do risível e do julgamento de sua figura e expressão; em seguida, com a prisão dela, a chave acionada é a da criminalização atrelada ao escárnio e ao racismo institucional; diante da candidatura política, há o apontamento de que ela estaria fora do lugar - e é justamente por romper a barreira de um espaço não reservado a ela que Andreza, ali, mais claramente resiste, tenta restituir a vida e a humanidade -; por fim, o assassinato e o luto negado. de Andreza tenham sido midiatizados, as imagens geradas acabaram por desumanizá-la, não garantiram reconhecimento. Fabiana Moraes (2011) lembra que tornar-se visível não é sempre igual a ter reconhecimento, pode, ao contrário, levar à subjugação. Enquadrada em imagens de controle (HILL COLLINS, 2019), Senhorita Andreza alcança uma visibilidade incompleta. Sua visibilização desumanizante é, portanto, fraturada, por conta do racismo e das opressões de gênero e classe que, mesmo diante de um sujeito visível, mantém invisível sua humanidade.

Um passo para reumanizar de alguma forma vidas subalternizadas como a de Andreza de Souza é seguir o que sugere Bell Hooks (2019): transformar as imagens, subvertê-las, mas mudar também as perspectivas e os modos de ver. São mudanças coletivas no imaginário que repercutem no lugar social garantido aos sujeitos colonizados. Vincular-se eticamente à tarefa dessa dupla 


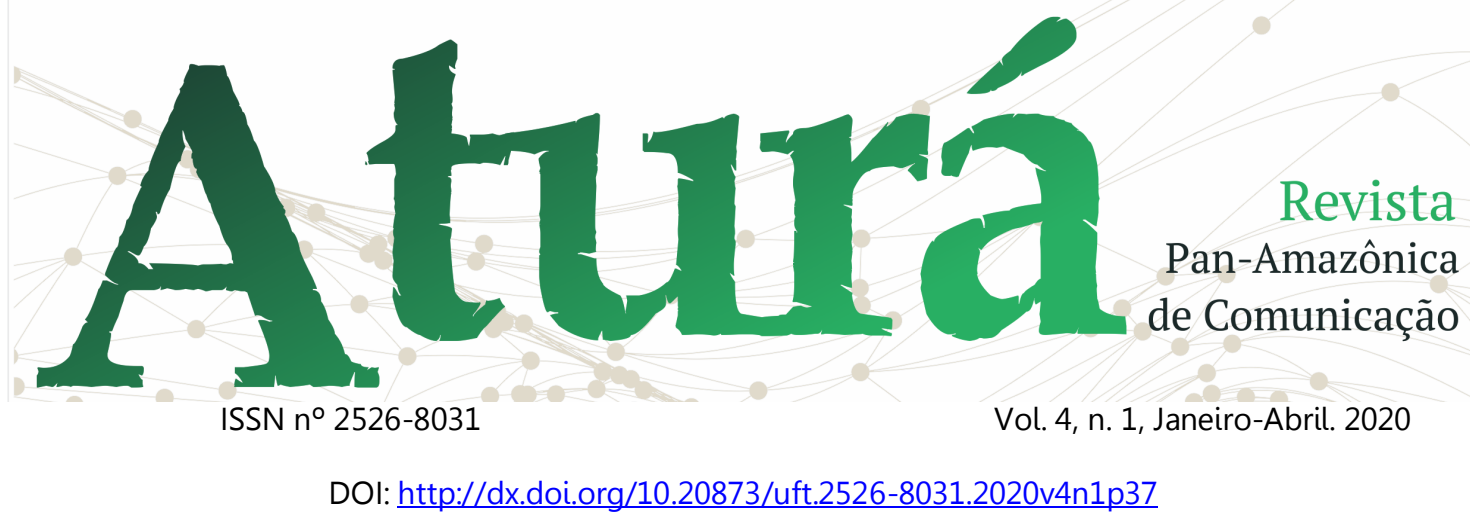

transformação pode ser um começo para a prática da descolonização.

\section{Referências}

BORGES, Juliana. Encarceramento em massa. São Paulo: Sueli Carneiro / Pólen, 2019.

CARNEIRO, Sueli. Mulheres negras e poder: um ensaio sobre a ausência. [2015?] Disponível em: http://www.articulacaodemulheres.org.br/ wp-content/uploads/2015/06/TC-6-

CARNEIRO-Suely-Mulheres-Negras-ePoder.pdf. Acesso em: 20 jul. 2019.

COUTO, Aiala Colares de Oliveira. Do poder das redes às redes do poder: necropolítica e configurações territoriais sobrepostas do narcotráfico na metrópole de Belém-PA. 2018. 300 f. Tese (Doutorado em Ciências: Desenvolvimento Socioambiental) - Núcleo de Altos Estudos Amazônicos, Universidade Federal do Pará, Belém, 2018. Disponível em: http://repositorio.ufpa.br/jspui/bitstream/ 2011/10461/6/Tese PoderRedesRedes.pdf . Acessso em: 28 jun. 2019.

FANON, Frantz. Os condenados da terra. Juiz de Fora: Ed. UFJF, 2005.

FANON, Frantz. Pele negra, máscaras brancas. Salvador: EDUFBA, 2008.

GONZALEZ, Lélia. Racismo e sexismo na cultura brasileira. [1980] In: GONZALEZ, Lélia. Primavera para as rosas negras -
Lélia Gonzalez em primeira pessoa. [S. l.] Diáspora Africana: Editora Filhos da África, 2018.

HILL COLLINS, Patricia. Pensamento feminista negro: conhecimento, consciência e a política do empoderamento. São Paulo: Boitempo, 2019.

HOOKS, Bell. Olhares negros: raça e representação. São Paulo: Elefante, 2019.

LUGONES, María. Rumo a um feminismo descolonial. Estudos Feministas, Florianópolis, v.22, n.3, p.935-952, set./dez $2014 . \quad$ Disponível em: https://periodicos.ufsc.br/index.php/ref/ar ticle/view/36755/28577. Acesso em: 12 jul. 2019.

MALDONADO-TORRES, Nelson. Sobre la colonialidad del ser: contribuciones al desarrollo de un concepto. In: CASTROGÓMEZ, Santiago; GROSFOGUEL, Ramón (orgs.). El giro decolonial: reflexiones para una diversidad epistémica más allá del capitalismo global. Bogotá: Siglo del Hombre, 2007. Disponível em: http://www.unsa.edu.ar/histocat/hamoder na/grosfoguelcastrogomez.pdf. Acesso em: 12 jul. 2019.

MBEMBE, Achille. Necropolítica: biopoder, soberania, estado de exceção, política da morte. São Paulo: n-1 edições, 2018.

MIGNOLO, Walter. La idea de América Latina: la herida colonial y la opción decolonial. Barcelona: Gedisa, 2007. Disponível em: 


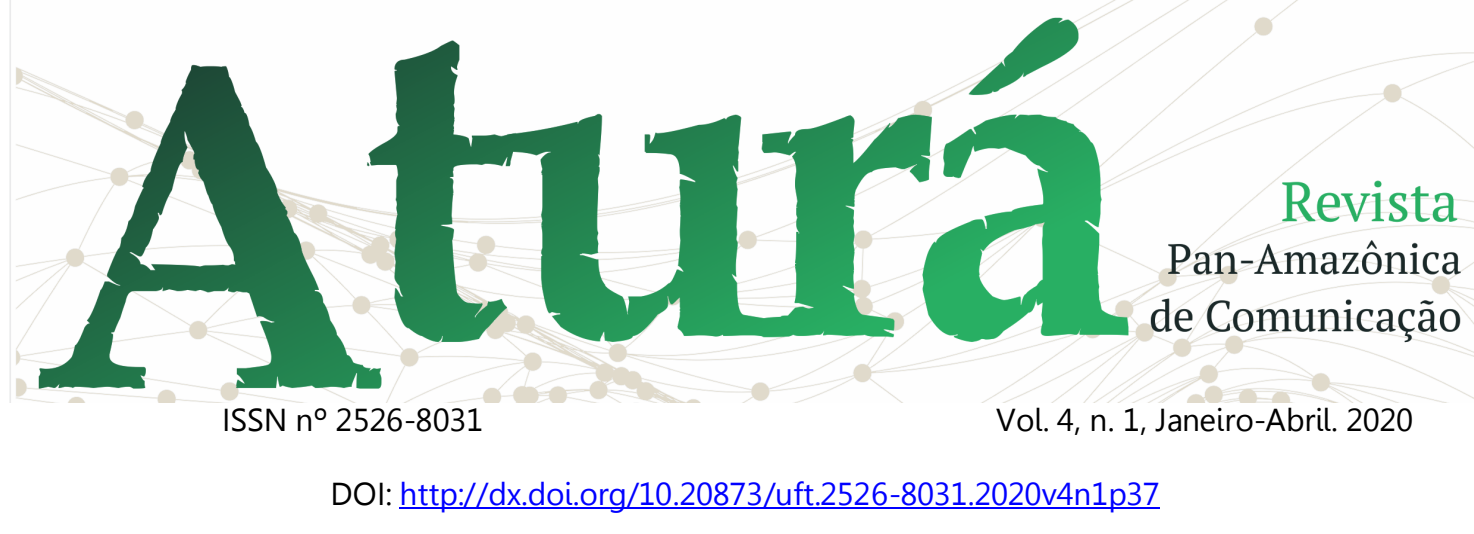

http://www.ceapedi.com.ar/imagenes/bibl ioteca/libreria/420.pdf. Acesso em: 12 jul. 2019.

MORAES, Fabiana. É tu nada, estrela: revista Caras e o consumo da felicidade nos salões de beleza de periferia. 2011. $259 \mathrm{f}$. Tese (Doutorado em Sociologia) Programa de Pós-Graduação em Sociologia, Universidade Federal de Pernambuco, Recife, 2011. Disponível em: https://repositorio.ufpe.br/bitstream/1234 56789/9599/1/arquivo7035 1.pdf. Acesso em: 28 jun. 2019.

QUIJANO, Aníbal. Colonialidade do poder, eurocentrismo e América Latina. In: A Colonialidade do Saber: eurocentrismo e ciências sociais. Perspectivas latinoamericanas. CLACSO, 2005, p. 116142. Disponível em: http://biblioteca.clacso.edu.ar/clacso/sursur/20100624103322/12 Quijano.pdf.

Acesso em: 20 jun. 2019.

QUIJANO, Aníbal. Colonialidade do poder e classificação social. In: SANTOS, Boaventura de Sousa; MENESES, Maria Paula (org.). Epistemologias do sul. Coimbra: Almedina / CES, 2009. Cap.2, p.73-117.

QUIJANO, Aníbal. "Raza", "etnia" y "nación" en Mariátegui: cuestiones abiertas. In: Cuestiones y horizontes: de la dependencia histórico-estructural a la colonialidad/descolonialidad del poder. Buenos Aires: CLACSO, 2014. Disponível em:

http://biblioteca.clacso.edu.ar/clacso/se/2 0140507040653/eje3-7.pdf. Acesso em: 20 jun. 2019.

SANTOS, Thandara (org.). Levantamento nacional de informações penitenciárias INFOPEN Mulheres, 2a edição. Brasília: Ministério da Justiça e Segurança Pública/ Departamento Penitenciário Nacional, 2017. Disponível: http://depen.gov.br/DEPEN/depen/sisdep en/infopenmulheres/infopenmulheres arte 07-0318.pdf. Acesso em: 20 jul. 2019.

SEIXAS, L. VALORES NOTÍCIA: uma proposta de análise. Revista Observatório, v. 4, n. 4, p. 334-366, 29 jun. 2018.

SILVA, Marco Antonio Batista. Racismo Institucional: pontos para a reflexão. Laplage em Revista. vol. 3, $n^{\circ}$ 1, 2017. Disponível em: http://www.laplageemrevista.ufscar.br/ind ex.php/lpg/article/view/223/472. Acesso em: 20 jul. 2019.

TRINDADE JÚNIOR, Saint-Clair Cordeiro da. Formação metropolitana de Belém (1960-1997). Belém: Paka-Tatu, 2016. 